\title{
A ConstruÇão de TEMPlos: \\ A Arquitetura Religiosa no Período Augustano
}

Macsuelber de Cássio Barros da Cunha ${ }^{1}$

\section{RESUMO}

O templo era uma das principais expressões da cultura material no que se refere à religião e à religiosidade no Mundo Antigo. Na Roma do período augustano não era diferente, de tal forma que a construção de templos obedecia a regras precisas, além de estar ligada a estratégias políticas, pois conferia glória aos seus responsáveis. Neste trabalho, analisamos o processo de construção de templos, suas características gerais e as principais regras para a construção da moradia das divindades, bem como a importância que a construção de templos teve neste período. Para tanto, nos utilizamos do $D e$ Architectura, de Vitrúvio, bem como dos vestígios da cultura material da época.

\section{PALAVRAS-CHAVE}

Templos; Augusto; Vitrúvio.

1 Professor do Instituto Federal de Educação, Ciência e Tecnologia Goiano, Campus Trindade. Doutor em História pelo Programa de Pós-Graduação em História da Universidade Federal de Goiás. É membro do Laboratório de Estudos sobre o Império Romano (LEIR-GO). E-mail: macsuelber@hotmail.com. 
Mare Nostrum, ano 2020, v. 11, n. 2.

\section{Introdução}

Sabemos da grande importância que a cultura material desempenha no estudo e na compreensão das sociedades e de determinados acontecimentos históricos. Em se tratando de História Antiga, os produtos da cultura material, geralmente revelados pelo trabalho de arqueólogos, são tão importantes quanto as fontes escritas, de tal modo que, apesar dos diferentes modos de lidar com fontes escritas e materiais, ambas são valiosas fontes de informações. No entanto, devemos destacar que, no que se refere à cultura material, uma definição única é algo difícil de conseguir devido ao fato de que a noção de cultura material é bastante heterogênea. Numa definição simplória, poderíamos dizer que a cultura material se refere a tudo aquilo de material que é produzido por uma sociedade, tudo que é feito ou utilizado pelo homem (Funari, 2005, p. 85).

Uma das áreas em que a cultura material teve destaque foi na religião. De acordo com Claudia Beltrão (2008, p. 15), “falar em 'religião romana' é falar de uma vasta categoria, que compreende diferentes elementos e um enorme número de práticas, instituições e crenças". Devemos lembrar que não existia em Roma uma distinção ou separação entre a esfera religiosa e secular, tal como a entendemos na atualidade, pois a religião estava presente em todos os momentos da vida em sociedade; como, por exemplo, nas decisões dos magistrados em que não se distinguia, à época, o que era política e o que estava na esfera do religioso. "Aqueles que detinham o poder político controlavam o acesso aos deuses; aqueles que controlavam o acesso aos deuses detinham poder político" (McEwen, 2003, p. 188). Assim, a religião romana era uma religião cívica, na qual os membros da sociedade buscavam desempenhar suas funções religiosas do melhor modo possível para com isso agradar aos deuses e garantir a pax deorum.

Quando lidamos com a religião e a religiosidade no Mundo Antigo, podemos afirmar que o templo era uma das principais expressões da cultura material. Ao lado desta cultura material está o que podemos chamar de cultura imaterial, representada pela escrita. Com isso, defendemos que a utilização da arquitetura, das imagens e de outros produtos da cultura material, juntamente com o documento observável pela imaterialidade da escrita (a epigrafia, a poesia, a prosa e a inscrição numismática) tiveram, no governo de Otávio Augusto, um papel ativo na constituição da sociedade e em sua

relação com a religião. Mesmo porque, assim como a escrita, as imagens detinham um 
grande poder: poder didático, de convencimento, político, propagandístico ${ }^{2}$, dentre outros. E Augusto soube se utilizar deste poder a seu favor, se apropriando de um costume que já estava presente na República (qual seja, o de se utilizar da arquitetura e das imagens para ligar o próprio nome a grandes feitos, a deuses, a heróis e assim manter seu nome vivo na memória da posteridade), levando este uso da cultura material a um alto grau de refinamento, grandiosidade e complexidade, de tal modo que, sob seu governo, Roma atingiu um nível de monumentalidade nunca visto até então, o que fez com que Augusto fosse emulado por muitos outros imperadores que vieram depois dele.

Ao longo de todo o seu governo, Otávio Augusto desenvolveu um amplo esforço construtivo, no qual se utilizou da arquitetura para engrandecer Roma, tornando-a digna de ser a capital do Império, além de ampliar a maiestas imperii por meio da egrégia autoridade dos edifícios públicos. Dentre os diversos edifícios públicos por ele construídos ou reformados, os templos possuíram lugar de destaque, demonstrando sua preocupação no que diz respeito a uma correta relação com as divindades. Tal aspecto pode ser percebido, por exemplo, nas Res Gestae, pois de todos os monumentos que ele declara ter feito $(f e c i)$, a grande maioria trata-se de arquitetura religiosa, o que demonstra a grande preocupação que ele dedicou a esse tipo de construção.

Ainda no período do triunvirato, ele iniciou a construção de um templo dedicado ao divino César, o qual foi inaugurado em 29 a.C. numa das extremidades do fórum romano, o coração de Roma. No ano de 28 a.C., ele se empenhou na restauração de diversos templos. Com relação especificamente a isso, o próprio Otávio declarou: "Reformei oitenta e dois templos dos deuses na Vrbs em meu sexto consulado e pela autoridade senatorial, nada negligenciando do que era, então, preciso reformar"3 $(R G D A, 20)$. Este ano também ficou marcado na história augustana por ter sido o ano em que o esplêndido templo de Apolo, no Palatino, foi consagrado. Este templo é um dos três que Augusto erigiu ex nоио, por sua própria iniciativa e com seus próprios fundos, sendo também o primeiro dos três a ser consagrado. O segundo templo é o de Júpiter Tonante, consagrado

\footnotetext{
2 De acordo com Ana Teresa Marques Gonçalves (2013, p. 42), "o termo propaganda vem do verbo latino propagare, do substantivo propagatio, que significava ampliar, alargar, estender espaços, difundir, implantar ou prolongar, prorrogar tempos. Assim, propagator era o título de um magistrado, bem como um dos epítetos de Júpiter, aquele que amplia, que engrandece, que conquista o Império" (Busino, 1980, pp. 275-276). Deste modo, ao tratar sobre a arquitetura, podemos dizer que ela serviu também como instrumento político de propaganda, visto que permitia a construção e a difusão sistemática de mensagens destinadas a um público difuso, visando criar uma imagem positiva do governante (Gonçalves, 2013, p. 46).

${ }^{3}$ Duo et octoginta templa deum in urbe consul sextum ex auctoritate senatus refeci nullo praetermisso quode o tempore refici debebat (Trad. do latim para o português por M. Trevizam, P. S. Vasconcellos e A. M. Rezende).
} 
Mare Nostrum, ano 2020, v. 11, n. 2.

em 22 a.C. no Capitólio. O terceiro e último templo construído em Roma por Augusto é o de Marte Vingador, localizado no Fórum de Augusto, consagrado em 2 a.C. ${ }^{4}$

Devido a isso, neste trabalho abordamos os aspectos concernentes à construção de templos no período augustano. Para tanto, nos utilizamos de alguns vestígios da cultura material, bem como da obra de Vitrúvio, autor do único tratado sobre Arquitetura escrito na Antiguidade a chegar a nossos dias, o De Architectura, dedicado a Otávio Augusto e publicado provavelmente em 27 a.C.

\section{O templo no Mundo Antigo}

Quando tratamos das construções religiosas do mundo antigo, primeiramente devemos abordar a etimologia da palavra templo. Tal palavra vem do latim templum; no entanto, como nos alerta Pierre Gros (2002, p. 122), a aparente equivalência entre os termos templum e templo não deve nos induzir ao erro, já que o termo latino não é coextensivo ao termo moderno. Segundo Luc Benoist, a palavra templum vem de tempere, que significa dividir: "O templo designou em primeiro lugar um setor do céu delimitado pelos áugures, [...]. Posteriormente aplicou-se esta palavra ao local do edifício onde a observação era feita, [...]” (Benoist, 1999, p. 75). Segundo John W. Stamper (2005, p. 10), um templum era um espaço no céu ou na terra, marcado por um áugure. Na terra, um templum era um lugar reservado e limitado por certas palavras sacramentais para a tomada dos auspícios. Este era um lugar especial, permanentemente inaugurado, assim designado por um augurium. No céu, o templum era uma parte delimitada na qual os áugures observavam o presságio dos deuses. Ainda de acordo com este autor, os romanos distinguiam entre um templum para observar relâmpagos e um para observar o voo dos pássaros, cada um dos quais tinha sua própria orientação. O templum para a observação de relâmpagos era orientado do ponto de vista dos deuses, que se sentavam em sua morada setentrional e olhavam para o sul; a observação dos pássaros, em contraste, era realizada em um cenário no qual o áugure olhava para o leste.

De acordo com Gros (2002, p. 122), os templa mais antigos eram quadriláteros desprovidos de qualquer construção, os quais eram delimitados pelo áugure por meio da effatio, ritual no qual, orientado de acordo com os pontos cardeais, o espaço inaugurado era subdividido por medianas marcadas no chão por meio de pregos e circunscrito da

\footnotetext{
${ }^{4}$ Para Suetônio (Aug. 29), estes três templos são as três principais obras públicas edificadas por Augusto.
} 
maneira mais rigorosa, embora não obrigatoriamente materializada. Segundo Daniel J. Gargola (1995, p. 26), o objetivo da effatio era separar lugares traçando seus limites externos. Além disso, os áugures realizavam também a liberatio da área, ou seja, removiam as indesejadas influências humanas ou sobrenaturais do terreno. Desta forma, “o objetivo de tal processo de inauguração, o resultado de uma liberatio e de uma effatio, foi instituir um espaço ou zona ritualmente definida, um locus inauguratus", cujo mais comum era o templum.

Deste modo, podemos afirmar que todo lugar ritualmente orientado e inaugurado era um templum e "assim, qualquer ação oficial realizada em um local veio, pelo menos idealmente, ou em teoria, com a aprovação divina” (McEwen, 2003, p. 166). Vemos com isso que em Roma diversos espaços públicos poderiam ser classificados com o termo templum, por terem sido delimitados pelos áugures; já a construção dedicada a servir de moradia às divindades, que hoje chamamos de templo, era na Antiguidade mais comumente tratada como aedes ${ }^{5}$.

No que diz respeito à tomada dos auspícios no local (templum) em que o templo (aedes) seria construído, Heinz Kähler (1965, p. 30) nos lembra que uma cabana de madeira representando o templo era erigida neste local, e, no dia em que a primeira pedra deveria ser colocada, o sacerdote assumia sua posição na porta da cabana, a fím de interpretar a vontade dos deuses por meio do voo dos pássaros. Antes, porém, de começar a tomar os auspícios, ele pegava o lituus e designava com ele, proferindo a fórmula tradicional, a área em frente à cabana para a qual suas observações seriam válidas. Ao indicar marcos específicos como árvores, pedras ou topos de morros, ele delimitava os limites de seu campo de observação. Além disso, segundo este autor, por esse ato o áugure subordinava o espaço diante dele ao templo, no qual o lugar em que estava seria ocupado pela estátua do deus. Este autor defende que a forma do templo significava algo ainda mais importante, que o templo estava relacionado ao espaço à sua frente e o dominava. "Dominação de um espaço claramente definido e alinhamento em um eixo preciso são qualidades enraizadas nas origens do santuário do templo romano” (Kähler, 1965, p. 30).

\footnotetext{
${ }^{5}$ Segundo Ian M. Barton (1995, p. 67), da ideia de um recinto dedicado a fins religiosos, relacionada ao termo templum, o significado é estendido e passa a denotar a construção que era geralmente a característica dominante do lugar, se originando assim o nosso termo templo; contudo, o termo latino correto para este tipo de construção é aedes. Além disso, de acordo com este autor, era possível existir um templum sem uma aedes, mas uma aedes (enquanto moradia da divindade) só poderia se localizar dentro de um templum. No entanto, é preciso que estejamos atentos para o fato de que a palavra aedes possui também outros significados; para os vários usos de aedes na língua latina (como casa, moradia, tumba) conferir o dicionário Oxford de Latim (2012, p. 68).
} 
Mare Nostrum, ano 2020, v. 11, n. 2.

Quanto aos termos templum e aedes, devemos destacar que Augusto, em suas Res Gestae, se utiliza dos dois termos, de modo aparentemente anárquico, para tratar dos empreendimentos arquitetônicos ou das restaurações realizadas por ele. No entanto, como defende Pierre Gros (1976, p. 15), há uma diferenciação, por parte do princeps, na forma de empregar os dois termos, de modo que a diferença entre ambos subsiste no nível de importância monumental, de forma que aedes estaria relacionado a edifícios religiosos isolados, enquanto que templum designaria complexos sagrados.

Em nosso trabalho, sempre que usamos o termo 'templo' estamos nos referindo especificamente às construções destinadas a abrigar as estátuas dos deuses, ou seja, à moradia dos deuses. A estátua de culto que se localizava na cela era mais do que uma simples representação do deus, sendo venerada como o próprio deus ali presente ${ }^{6}$.

Os rituais realizados diante da estátua de culto são um meio de comunicação religiosa e de atendimento aos deuses: as imagens do culto são 'acordadas' pela manhã, recebem refeições regulares, são perfumadas e vestidas, até têm seus rostos pintados, seus corpos embelezados e são 'entretidas' com passeios e procissões, apresentações musicais e teatrais (Gladigow, 1994, pp. 19-24, apud. Egelhaaf-Gaiser, 2007, p. 210).

Devido a isso, o templo antigo, sendo a moradia dos deuses, não era aberto ao público para a adoração da divindade sempre que se quisesse. Pelo contrário, até mesmo os rituais próprios das tradições religiosas compartilhadas pela comunidade, como os sacrifícios, por exemplo, não eram realizados dentro dos templos, mas nos altares localizados à sua frente.

De acordo com Ulrike Egelhaaf-Gaiser (2007, p. 209), tanto as fontes arqueológicas quanto as literárias enfatizam a distância e a proximidade desejada com a divindade. As portas do templo normalmente ficavam fechadas e cortinas eram usadas na cela, de modo

\footnotetext{
${ }^{6}$ De modo geral, havia diferentes termos para designar a ampla variedade de esculturas que hoje denominamos como estátuas. Como nos esclarece Peter Stewart, em seu livro sobre estátuas na sociedade romana, o latim tem uma palavra para 'estátua' - statua, mas este não é o único termo para uma escultura, pois uma variedade de outras palavras é usada. As palavras mais frequentes são simulacrum e signum. Para este autor, as estátuas de culto localizadas no interior dos templos eram geralmente denominadas com o termo simulacrum, que poderia ser empregado para se referir a todo tipo de imagens e representações, mas quando se tratava de uma estátua, tal imagem era quase sempre de um deus e neste caso uma estátua de culto. Signum denotava imagens de deuses no geral, mas também poderia ser utilizada para 'obras de arte'. Já statua se referia quase sempre às esculturas independentes de mortais. No entanto, como esclarece o autor, estes termos não estão separados por rígidas barreiras semânticas (Stewart, 2003, pp. 21-23).
} 
que todas as imagens de culto ficassem ocultadas da visão, e o acesso era concedido pelos guardiões do templo (aedituus) apenas mediante solicitação. Ademais, dentro do templo, grades e cercas impediam o visitante de entrar em áreas onde apenas especialistas de culto ou iniciados nos mistérios podiam entrar. Nesta mesma perspectiva, Stamper (2005, p. 14) esclarece que, no templo de Júpiter Optimus Maximus, por exemplo, geralmente sacerdotes e certos magistrados eram os únicos a entrar nas celas do templo, as quais eram escassamente mobiliadas, abrigando apenas as estátuas de culto e pequenos altares para queimar incenso. Tudo isso demonstra a aura de respeito e as rígidas regras de acesso que os templos possuíam por serem a moradia das divindades.

\section{A Tradição Republicana na Construção de Templos}

Durante a República, foi comum importantes personalidades dedicarem templos em honra aos deuses e fazerem questão de ligar seus nomes à construção dos mesmos. De acordo com Eric Orlin (2002, p. 193), “o objetivo de um aristocrata romano não era meramente superar seus contemporâneos, mas ofuscar todos os que o haviam precedido e estabelecer um padrão para as futuras gerações". Tais obras mantinham vivos os nomes daqueles que haviam propiciado tais obras à cidade, como de generais, por exemplo, ou da família por trás de sua construção.

A conexão familiar com um templo em particular poderia continuar nas gerações posteriores, [...] do ponto de vista dos generais, esta era uma inestimável oportunidade de usar o espaço público como um memorial permanente de suas realizações; do ponto de vista da cidade, ele era uma mostra de seus triunfos e despojos ao longo dos séculos; do ponto de vista dos deuses, ele era uma demonstração de seu contínuo envolvimento no progresso da expansão romana (Beard, North, \& Price, 1998, p. 88).

No que se refere à edificação de templos durante a República, Strong (1968, p. 99) nos informa que a construção de edifícios sagrados não se enquadrava no âmbito da administração normal das obras públicas, de modo que novos templos eram geralmente prometidos em tempos de tensão, especialmente de guerra e, muitas vezes, in medio discrimine pugnae. Portanto, eram construídos de acordo com regras muito precisas. Somente um magistrado cum imperio podia prometer um templo. Segundo Orlin (2002, 
Mare Nostrum, ano 2020, v. 11, n. 2.

pp. 19-20), as circunstâncias em que os novos templos foram prometidos podem ser divididas em duas grandes categorias. Alguns foram prometidos em resposta a uma situação civil interna envolvendo apenas os romanos e seus deuses. Incluem fenômenos naturais como pragas, secas e outros portentos, bem como crises internas, como um motim. Outros templos, a grande maioria, foram prometidos como resposta a uma situação militar externa envolvendo um inimigo estrangeiro. Para este autor, todas essas situações apresentavam crises que ameaçavam o bem-estar, ou às vezes a própria existência, do Estado romano, e assim a pax deorum teria sido uma preocupação primordial. Além disso, um templo poderia ser construído em agradecimento após a resolução bem-sucedida de uma crise interna ou após a vitória romana sobre o inimigo.

Como nos esclarece Ziolkowski (1992, p. 193), a fundação de um novo templo era um processo longo, complexo e multifacetado que compreendia as datas de seu votum, locatio e dedicatio. O votum consistia na promessa realizada, muitas vezes por um general em campo de batalha, para a construção de um templo dedicado a alguma divindade, de modo que este era devidamente construído após a conclusão bem-sucedida da campanha militar e do retorno do general a Roma. Segundo Orlin (2002, pp. 44-50), apesar de templos também terem sido prometidos por generais antes de deixar Roma para suas campanhas, o mais comum eram os votos feitos em campanha, pelos quais os novos templos foram construídos em solo romano. Este autor esclarece ainda que, no mundo romano, um votum funcionava como um contrato sagrado, isto é, um tratado entre uma entidade humana e uma entidade divina, estipulando que se o divino proporcionasse assistência oportuna, o humano responderia com uma honra específica. Além disso, novos templos também poderiam ser construídos em Roma após a consulta aos Livros Sibilinos ${ }^{7}$.

A locatio de um templo, de acordo com Ziolkowski (1992, p. 204), “deve ter sido um ato solene, que não pode ser limitado a organizar a construção desse templo". Já para Eric Orlin (2002, p. 139), a locatio foi o primeiro passo na construção de qualquer edifício público em Roma, mas o fato de ter sido pouco tratada pelos autores antigos deve refletir o sentimento geral com relação à construção de novos templos, de forma que a locatio não deve ter sido um momento significante como o votum e a dedicatio. Além disso, este

\footnotetext{
${ }^{7}$ Os Livros Sibilinos se constituíam numa coleção de oráculos mantidos no templo de Júpiter Capitolino e consultados principalmente em momentos de crise. Por volta de 23 e 19 a.C. foram transferidos para o Templo de Apolo, no Palatino, ficando assim ligados ao aspecto profético deste deus.
} 
autor nos informa que não sabemos absolutamente nada sobre o processo pelo qual o local era escolhido para a construção de um novo templo.

Durante a República, a construção de edifícios públicos, de modo geral, era de responsabilidade dos censores ou edis, e, na ausência de censores, os deveres eram conferidos aos cônsules e aos pretores. No que se refere aos templos, os romanos criaram um cargo separado cuja única função era supervisionar a construção de um templo particular, os duumuiri aedi locandae. Isso demonstra que os contratos para a construção de templos foram colocados em uma categoria separada de outros edifícios públicos. Como afirma Orlin (2002, pp. 147-148), censores, cônsules, ditadores e edis poderiam ser responsáveis por contratos para a construção de templos, mas nenhum pode ser considerado como tendo realizado regularmente essa tarefa. Este ponto destaca o fato de que os romanos trataram os assuntos religiosos com cuidado especial, para garantir a pax deorum e a segurança do Estado romano. De modo que, para este autor, a instituição dos duumuiri desempenhou um papel significativo na fundação de novos templos, tanto na construção quanto na dedicação, já que também existiam os duumuiri aedi dedicandae, que foram responsáveis pela dedicação de alguns templos durante a República.

A dedicatio de um templo era o momento mais importante e que conferia maior prestígio ao patrono responsável pela construção. Por meio da dedicatio é que a fundação do templo era alcançada. Deste modo, o processo era longo e possuía diversas etapas. Havia sido iniciado com a promessa (votum) de construção do templo, geralmente realizada por um general em campo de batalha. Havia passado pelo processo de delimitação do terreno onde o templo seria construído, processo esse que era realizado pelos áugures, que procediam à inauguratio do espaço sagrado (templum), resultado direto da liberatio e da effatio. Havia passado também pelo processo de planejamento e construção até chegar à sua conclusão, com a cerimônia pomposa da dedicatio, presidida geralmente pelo mesmo magistrado que havia prometido o templo, momento no qual ocorria também a consecratio do templo à divindade à qual era destinado, sendo este ritual presidido por um pontifex.

[...] Diversos aspectos da dedicatio estão cheios de implicações para a política romana e para a religião romana, especialmente a identidade dos indivíduos que realizavam a dedicatio. [...] A pessoa que prometia um novo templo, fornecia a si mesmo uma fama duradoura, visto que era provável que seu nome fosse lembrado em conexão com o templo. Mas a dedicatio, que era realizada com grande pompa 
Mare Nostrum, ano 2020, v. 11, n. 2.

e muitas vezes acompanhada de jogos, oferecia uma forma mais imediata de gloria, mais diretamente aplicável à concorrência entre os aristocratas de Roma (Orlin, 2002, p. 162).

De acordo com Stamper (2005, p. 39), enquanto o controle final sobre a construção e a dedicação de templos estava nas mãos de censores, generais e magistrados, a autoridade administrativa do sistema religioso de Roma estava nas mãos dos sacerdotes e suas organizações, os collegia. Durante o início da República, havia vários collegia: os pontifices, os augures e os duouiri (mais tarde aumentados para dez, decemuiri, e depois para quinze, quindecimuiri). Além destes pode ser adicionado um quarto collegium, os fetiales $^{8}$. Como este autor nos lembra, os membros desses collegia eram recrutados das fileiras da oligarquia dominante e eram regularmente consultados como especialistas pelos cônsules e pelo Senado. Os pontífices tinham um líder reconhecido, o pontifex maximus.

\section{Augusto e a Arquitetura Religiosa}

A importância que a construção e a restauração de templos possuía para aumentar a glória do responsável por tais obras foi tanta que, como vimos, após voltar vitorioso a Roma em 29 a.C., Augusto dedicou o templo de César divinizado, consagrou, no ano seguinte, o templo de Apolo no Palatino e promoveu a restauração de mais de 80 templos em Roma. Tais reformas arquitetônicas empreendidas por Otávio se ligavam a uma mais ampla restauração religiosa e dos ritos tradicionais que ele também empreendeu. De acordo com John Scheid (2007, p. 177), a restauração empreendida por ele foi uma reação à negligência dos deveres rituais públicos e dos templos, ocorrida devido às desordens das guerras civis, e que estas restaurações eram parte de seus objetivos políticos, visto que "restaurar a Res Publica automaticamente significava restaurar suas instituições religiosas e lugares de culto, especialmente quando eles tinham sido negligenciados ou mesmo esquecidos".

Em outro trabalho, Scheid (2009, pp. 124-125) desenvolve esta mesma temática, afirmando que as autoridades públicas, os magistrados, os sacerdotes e o Senado eram

\footnotetext{
${ }^{8}$ Sacerdotes de um colégio romano encarregado de realizar as cerimônias antes da declaração formal de guerra e de concluir e santificar o tratado de paz na conclusão de uma guerra. Os rituais eram elaborados e precisavam ser realizados com muito cuidado e pontualidade. Acredita-se que o colégio foi fundado por Numa Pompílio (Richardson, 1992, p. 438).
} 
encarregados das obrigações do povo romano e, por conseguinte, eram os responsáveis pela disfunção na vida religiosa pública, de forma que restaurar os deveres religiosos negligenciados era uma forma de recuperar a situação anterior.

O interesse demonstrado por Augusto em restaurar tais templos pode ser visto na literatura do período, por exemplo, quando Horácio escreveu no terceiro livro das Odes que os romanos pagariam pelos erros de seus ancestrais até que cada templo em ruínas fosse restaurado (Horácio. Carmina. 3. 6), ou em Tito Lívio, que no livro quarto de sua obra se refere a Otávio como "fundador ou restaurador de todos os santuários" 9 (Tito Lívio. Ab Urbe Condita. 4. 20. 7). ${ }^{10}$

Além disso, Augusto ligou algumas de suas construções ou reconstruções com datas importantes para ele, de modo que vários templos receberam a mesma data de dedicação do seu aniversário. Como a data da dedicação de um templo tornava-se seu dies natalis, este aniversário inserido no calendário e celebrado anualmente pelos devotos sublinhava ainda mais a imagem de Augusto.

Os templos, portanto, além de eternizar as qualidades e os defeitos que neles se encontrassem $^{11}$, também deveriam manter na memória das futuras gerações o nome daqueles que estavam por trás de tais obras, visto que a construção de templos sempre se ligou ao desenvolvimento e/ou manutenção do prestígio de quem os erigia. Além disso, como assevera Gros (1976, p. 41), os templos no período augustano se concebiam como sinais: sinais patentes da pietas restaurada; sinais da presença majestosa dos deuses tutelares de Roma no coração da cidade; sinais principalmente do poder do Principado e das forças superiores a partir das quais ele assegurou sua origem e sua perenidade. Segundo este autor, quando Vitrúvio (Vitrúvio. De Architectura, 1.Pr.2) afirma que "a dignidade do Império foi sublinhada pela egrégia autoridade dos edifícios públicos"12, o termo auctoritas possui aqui o sentido de crescimento, de aumento, e percebe-se que ele

\footnotetext{
9 “Templorum omnium conditorem aut restitutorem". (Trad. do latim para o inglês por Rev. Canon Roberts e para o português pelo autor deste artigo).

${ }^{10}$ Posteriormente, Suetônio em seu tempo também cita este empreendimento de Otávio, afirmando que este refez velhos templos ornando-os com doações riquíssimas (Suetônio. De Vita Caesarum, Diuus Augustus. 30).

${ }^{11}$ Vitrúvio possuía a concepção de que os templos eram obras eternas, o que pode ser percebido neste trecho: "Por conseguinte, se (os antigos) nos transmitiram regras para todas as construções, elas destinamse, sobretudo, aos templos dos deuses, porque as qualidades e os defeitos dessas obras permanecem eternos" (Vitr. De arch. 3.1.4). "Igitur cum in omnibus operibus ordines traderent, maxime in aedibus deorum, quod eorum operum et laudes et culpae aeternae solent permanere". (Trad. do latim para o português por M. Justino Maciel).

12 "maiestas imperii publicorum aedificiorum egregias haberet auctoritates" (Trad. do latim para o português por M. Justino Maciel).
} 
Mare Nostrum, ano 2020, v. 11, n. 2.

se aplica, sobretudo, aos edifícios religiosos, de preferência, dentro da visão de Vitrúvio, àqueles feitos em mármore e que respeitavam os paradigmas arquitetônicos do helenismo.

Conhecedor da importância que a construção de templos possuía, visto que o ligava diretamente aos deuses, Augusto se empenhou na construção e na restauração de templos em Roma, conseguindo que somente ele e sua família fossem os únicos a erigir templos na cidade. Sob o seu governo houve uma profunda mudança na paisagem arquitetônica de Roma, de modo que ele investiu altas $\operatorname{somas}^{13}$ na construção, reforma e engrandecimento de diversos edifícios públicos, concedendo um maior esforço e atenção aos templos, mesmo porque a restauração moral e religiosa era a palavra de ordem em seu governo. No período de Augusto, os templos em Roma se tornaram cada vez mais suntuosos, ricamente decorados, erigidos, ou pelo menos recobertos dos mais diversos mármores vindos de diversas partes do Império.

Ao mencionar estes templos nas Res Gestae (19 e 21), Augusto alega ter construído (feci) os templos de Apolo no Palatino, do Diuus Iulius, de Júpiter Ferétrio, de Júpiter Tonante no Capitólio, de Quirino, de Minerva, de Juno Rainha, de Júpiter da Liberdade no Aventino, dos Lares no topo da Via Sacra, dos deuses Penates em Vélia, da Juventude e o de Magna Mater no Palatino e o Templo de Marte Vingador. No entanto, não temos muitas informações sobre todos estes templos, de modo que não se sabe a data de consagração ou o local de alguns deles. Além disso, como esclarece Haselberger (2007, p. 218), alguns destes templos foram na verdade restaurados pelo imperador. De acordo com Gros (1976, p. 15), ao usar o termo feci para tratar destas e de outras obras, Augusto quis dizer: "eu construí ou reconstruí inteiramente às minhas custas".

Nas Res Gestae, de todos os monumentos que Augusto declara ter feito (feci), a grande maioria trata-se de arquitetura religiosa, ou seja, de templos, e todas estas construções, sem exceção, pelas quais ele assume responsabilidade estavam dentro da muralha que cercava a Vrbs (Haselberger, 2007, p. 264). Além disso, é interessante notar que assim como com Augusto a menção à construção religiosa é maior, também em

\footnotetext{
${ }^{13}$ Como o próprio Augusto ressaltou (RGDA. 20), ele teria gasto uma soma vultosa (impensa grandi) na reforma do templo de Júpiter Capitolino e no teatro de Pompeu. Em seu tempo Suetônio (Aug. 30) também nos fornece essa informação ao afirmar que Augusto "refez velhos templos desmoronados por sua antiguidade ou destruídos por algum incêndio e ornou-os e a outros com doações riquíssimas, chegando a empregar dezesseis mil libras de ouro e gemas e pérolas no valor de cinquenta milhões de sestércios no santuário de Júpiter Capitolino". "Aedes sacras uetustate conlapsas aut incendio absumptas refecit easque et ceteras opulentissimis donis adornauit, ut qui in cellam Capitolini Iouis sedecim milia pondo auri gemmasque ac margaritas quingenties sestertium una donatione contulerit" (Trad. do latim para o português por M. Trevizam, P. S. Vasconcellos e A. M. Rezende).
} 
Vitrúvio isso acontece, pois, em sua obra, dos dez livros que a compõem ele dedica dois ${ }^{14}$ a discorrer acerca da arquitetura religiosa, e, dentre todos os tipos de edifícios dos quais Vitrúvio tratou em sua obra, os templos são os primeiros, demonstrando assim a importância destes edifícios públicos para a sociedade de então e o seu respeito pelas divindades e sua moradia. Deste modo, passamos a tratar agora sobre algumas características gerais acerca da arquitetura dos templos a partir da obra de Vitrúvio.

\section{Vitrúvio e a construção de templos}

Ao tratar dos templos nos livros 3 e 4 de sua obra, Vitrúvio dedica a maior parte destes para explicar as ordens gregas dórica, jônica e coríntia, suas regras de construção, suas medidas, vantagens e/ou desvantagens de determinada ordem, etc. ${ }^{15}$ Ele elenca os diferentes tipos de templos de acordo com a disposição das colunas e com os intercolúnios, buscando sempre que possível citar exemplos de tais templos, sejam em solo romano ou fora dele, quando determinada tipologia não possuía exemplar em Roma. Além do que, na obra de Vitrúvio os templos tinham regras específicas para sua construção e tais regras estavam amplamente baseadas nas tradições construtivas legadas pelos gregos, de forma tal que, de todos os edifícios tratados por Vitrúvio, os templos são os que mais devem a estes paradigmas construtivos. Podemos perceber em sua obra que, no que tange à construção de templos, poucas inovações podem ser classificadas como genuinamente latinas. ${ }^{16}$

\footnotetext{
${ }^{14} \mathrm{O}$ terceiro e o quarto livros são dedicados especificamente à construção dos templos. No terceiro livro, Vitrúvio discutiu primeiramente a respeito da composição dos templos e a importância de estarem baseados na comensurabilidade; desenvolveu neste livro sua noção de templo enquanto obra eterna; traçou uma tipologia dos templos de acordo com a disposição das colunas e de acordo com os intercolúnios, bem como tratou de outras especificidades técnicas para a construção de templos, com maior ênfase para a ordem jônica. No quarto livro, ele traçou esclarecimentos acerca das diferentes ordens arquitetônicas, explicando, por exemplo, a origem (mítica) das ordens dórica, jônica e coríntia; desenvolveu outras especificidades técnicas das ordens dórica e coríntia, além de tratar acerca da orientação dos templos; tratou também especificamente dos templos toscanos; e finalizou este livro com um breve capítulo a respeito da construção de altares e as diferenças que deveriam possuir com relação aos deuses para os quais os sacrifícios seriam oferecidos.

${ }^{15}$ Além de tratar das regras constituintes das ordens gregas para construção de templos, Vitrúvio traz também a explicação sobre templos circulares e sobre outras tipologias de templos, que, em certa medida, não se enquadravam nas tipologias já explicadas por ele. Vitrúvio dedica ainda o capítulo 7 do quarto livro para tratar dos templos 'toscanos'.

${ }^{16} \mathrm{O}$ mesmo não pode ser dito de outras construções como, por exemplo, fóruns, teatros e casas, visto que as recomendações de Vitrúvio para estas construções possuem maior flexibilidade com relação aos paradigmas gregos, de tal modo que para estas construções os arquitetos deveriam estar atentos aos costumes antigos e tradicionais dos itálicos, respeitando, por exemplo, os diferentes usos e costumes entre gregos e romanos.
} 
Mare Nostrum, ano 2020, v. 11, n. 2.

No que diz respeito à tipologia dos templos de acordo com a disposição das colunas, Vitrúvio dedica o capítulo 2 do terceiro livro para explicar sobre os templos in antis, prostilo, anfiprostilo, períptero, pseudodíptero, díptero e hipetro. Dentre estes tipos de templo, devemos ressaltar o períptero, devido ao fato de que, a partir desta tipologia, se desenvolveram duas inovações essencialmente romanas. Sobre esta tipologia, Gros (2002, p. 130) afirma que a mesma não foi muito utilizada em Roma, pois a noção de uma área de circulação em torno da cela (ambulatio) jamais foi uma imposição, já que não tinha nenhuma fundamentação litúrgica. Uma das inovações que se derivou desta tipologia, e que Gros (2002, p. 126) engloba na categoria etrusco-itálica ${ }^{17}$ de templos, são os templos cuja colunata se encontra em três de seus lados, de modo que não há colunas na parte posterior do templo, sendo que a parede traseira da cela se estende até as colunas laterais, estabelecendo um limite à área de circulação. Estes templos são classificados por Vitrúvio (De arch. 3.2.5) como peripteros sine postico. Segundo Gros (1976, pp. 122124; 2002, pp. 126-127), esta tipologia se desenvolveu em Roma a partir do século IV a.C.; na República Tardia e no início do Principado, estes templos apresentavam todas as características do "períptero romano".

De acordo com Stamper (2005, p. 30), o principal templo romano, o de Júpiter Capitolino, seguia a tipologia do períptero sine postico, tipologia que teria influenciado os construtores romanos até a República. Além disso, variações são encontradas nos Templos de Vênus Genetrix e Mars Vltor. Segundo este autor, apesar de geralmente se supor que tenha sido comum na prática de construção etrusca, trata-se de um arranjo que foi encontrado mais predominantemente nas estruturas do templo latino.

A outra inovação derivada dos templos perípteros, e que se trata de algo essencialmente romano, é a tipologia de templos à qual Vitrúvio (De arch. 4.8.6) denomina pseudoperíptero. Segundo M. Justino Maciel (2007, p. 233), na nota de rodapé 110 de sua tradução do Tratado de Arquitetura, essa tipologia corresponde simultaneamente a uma necessidade de alargar ou manter o espaço da cela e ao espírito prático que leva a fundir as paredes da cela com as colunas, sendo estas muitas vezes apenas sugeridas. Como nos esclarece Gros (2002, pp. 131-133), este é o tipo de templo mais significativo do período entre o final da República e o início do Principado. Esta

\footnotetext{
${ }^{17}$ De acordo com Gros (2002, p. 123), na terminologia atual chama-se de templos toscanos aqueles que possuíam três celas, tal qual foi descrito por Vitrúvio (De arch. 4.7.1-5), e usa-se o termo mais geral de etrusco-itálico aos templos que possuíam uma ou mais das características do tipo: um traçado quadrangular; um pódio; uma escadaria de acesso frontal; uma parte anterior profunda e aberta na fachada; uma orientação voltada para o Sul, que permitia variações, de acordo com a necessidade; e uma estátua de culto situada no topo de uma das medianas do plano.
} 
tipologia surgiu no meio itálico no fim do século II a.C., ou seja, num momento em que a arquitetura grega exerceu uma influência direta sobre Roma.

[...] este tipo de templo devia conhecer em Roma um desenvolvimento sem precedentes: preservando sua orientação e frontalidade no templo Itálico, bem como a importância relativa de sua cela, ele permitiu o uso de uma colunata, cujo caráter fictício foi mais prontamente aceito do que a noção de ambulatio que permanecia estranha à própria concepção de templum. Criação compósita, comparável ao templo peripteros sine postico, mas talvez mais completa porque mais homogênea, ela alcançou a fusão das exigências religiosas próprias da tradição etrusco-itálica, e das novas contribuições da arquitetura helenística (Gros, 1976, pp. 121-122).

Dentre os templos que possuíam essa tipologia, podemos citar o templo dedicado a Portunus, no Fórum Boário, o templo de Saturno, no Fórum Romano, o templo de Apolo Sosiano, no Campo de Marte, e o templo de Apolo Palatino (Figura 1).
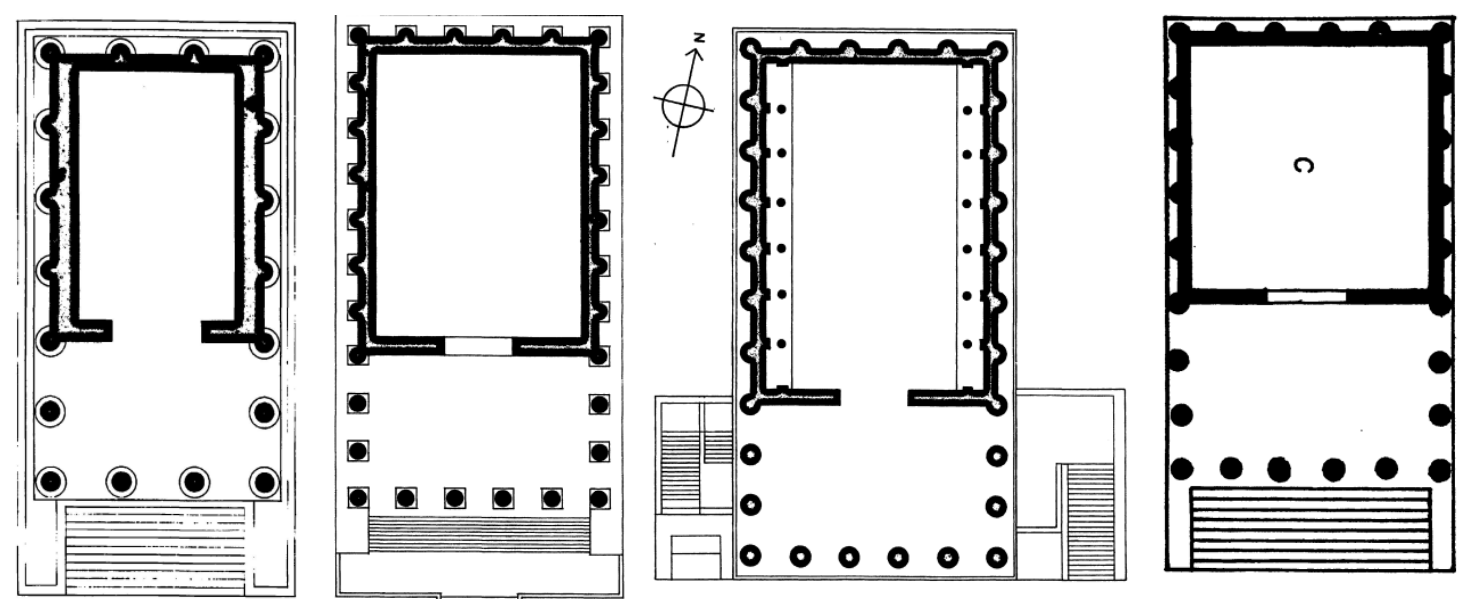

Figura 1. Exemplos de templos pseudoperípteros. Da esquerda para direita: Templo de Portunus, de Saturno, de Apolo Sosiano e de Apolo Palatino

Fonte: Stamper, $2005^{18}$.

No que se refere à tipologia dos templos quanto ao espaçamento entre as colunas, Vitrúvio (De arch. 3.3.1) esclarece que são cinco os tipos de templos: "Picnostilo, ou seja,

${ }^{18}$ As diferentes proporções dos templos não foram representadas aqui, já que o objetivo é apenas demonstrar exemplos de templos que se utilizavam desta tipologia. 
Mare Nostrum, ano 2020, v. 11, n. 2.

de colunas cerradas; sistilo, um pouco bastas; diastilo, mais amplamente abertas; areostilo, com colunas mais distanciadas entre si do que convém; e eustilo, com uma justa distribuição de intervalos"19. É interessante notar que dentre estes tipos de intercolúnios, o picnostilo ${ }^{20}$ foi o escolhido para o templo de Vênus Genetrix, construído por César em seu fórum, para o templo de César Divinizado e para o templo de Marte Vingador. ${ }^{21}$ Segundo Pierre Gros (2002, p. 141), o templo de Vênus Genetrix parece ter introduzido pela primeira vez em Roma o tipo picnostilo, uma concepção bem diferente da que prevaleceu na época precedente.

Para os arquitetos helenísticos a colunata que circunda a cela é somente um lugar de transição; independentemente de seu valor plástico e de seu papel, ela definiu um pórtico cujos suportes não deviam dificultar a passagem, seja da luz ou dos fiéis, em direção às estátuas de culto. No templo de Venus Genetrix e depois dele na maioria dos grandes edifícios de culto augustanos, as colunas, e principalmente aquelas da fachada, não se definem mais por referência a uma ambulatio da qual elas constituíam apenas o elemento limítrofe; elas possuem um significado que lhes é próprio, e que se afirmará ainda melhor se elas forem mais próximas e também mais altas (Gros, 2002, p. 141).

No que se refere às regras quanto à orientação que os templos e os altares deveriam seguir em Roma, Gros (1976, p. 147) esclarece que se trata de uma questão de difícil resolução, primeiro pelo fato de que as exigências de uma urbanização onde o que dominava era a busca por continuidade e monumentalidade parece ter relegado a preocupação quanto às regras de orientação a um segundo plano. Este aspecto demonstra também a flexibilidade com que certas regras eram vistas, de tal forma que em Vitrúvio podemos perceber este caráter, visto que ele esclarece a necessidade de se estar atento às exigências próprias de cada local no qual se ergueria um templo quando ressalta, por exemplo, que, apesar das regras ditarem certa orientação para o templo:

\footnotetext{
19 "Pycnostylos id est crebris columnis, systylos paulo remissioribus intercolumniorum spatiis, diastylos amplius patentibus, rarius quam oportet inter se diductis araeostylos, eustylos interuallorum iusta distributione" (Trad. do latim para o português por M. Justino Maciel).

${ }^{20}$ Segundo Vitrúvio (De arch. 3.3.2), picnostilo é o templo onde se pode preencher o intercolúnio com um diâmetro e meio de coluna. Nesta categoria também se encontram os templos cujo espaçamento entre as colunas é inferior a um diâmetro e meio da medida da coluna.

${ }^{21}$ Não há um consenso sobre qual seria o intercolúnio do templo de Apolo Palatino.
} 
Se, porém, a natureza do lugar impedir, deve-se mudar os ordenamentos dessas orientações, de modo que a maior parte do recinto fortificado da cidade possa ser avistada a partir dos templos dos deuses. [...] Se forem levantados edifícios aos deuses ao longo das vias públicas, serão de tal forma planejados que os transeuntes possam voltar os olhos e fazer as saudações na presença dos deuses ${ }^{22}$ (Vitr. De arch. 4.5.2).

Segundo Gros (1976, p. 147), além da questão das exigências urbanísticas, outra dificuldade ao se tratar de normas e regras quanto à orientação dos templos reside no fato de que não havia um consenso entre os antigos, de modo que praticamente todas as orientações tinham sua justificativa. De acordo com Vitrúvio, o templo deveria ter sua entrada voltada para:

[...] a região vespertina do céu, de forma que os que se aproximam do altar para imolar ou fazer sacrifícios olhem para a parte do céu nascente e para a imagem que estiver no templo, pois assim os que dirigem súplicas aos deuses poderão contemplar o templo e o oriente do céu, de onde parecerão surgir as próprias estátuas olhando complacentemente para os suplicantes e sacrificantes, porque parece necessário que todos os altares dos deuses estejam direcionados para o oriente $^{23}$ (Vitr. De arch. 4.5.1).

Os altares, que deveriam ser construídos em frente ao templo, possuíam grande importância na Antiguidade, pois, como lembra Orlin (2002, p. 11), o ato religioso essencial no mundo antigo era o sacrifício de animais, o qual era realizado nos altares, de tal forma que "um templo não era estritamente necessário para a realização de culto e sua construção foi muitas vezes um desenvolvimento secundário”. No que se refere à orientação deles, Vitrúvio traçou as seguintes diretrizes:

\footnotetext{
22 "Sin autem loci natura interpellauerit, tunc conuertendae sunt earum regionum constitutiones, uti quam plurima pars moenium e templis earum conspiciatur. [...] si circum uias publicas erunt aedificia deorum, ita constituantur, uti praetereuntes possint respicere et in conspectu salutationes facere" (Trad. do latim para o português por M. Justino Maciel).

23 “[...] spectet ad uespertinam caeli regionem, uti, qui adierint ad aram immolantes aut sacrificia facientes, spectent ad partem caeli orientis et simulacrum, quod erit in aede, spectet ad uespertinam caeli regionem, uti, qui adierint ad aram immolantes aut sacrificia facientes, spectent ad partemcaeli orientis et simulacrum, quod erit in aede, et ita uota suscipientes contueantur aedem et orientem caelum ipsaque simulacra uideantur exaudientia contueri supplicantes et sacrificantes, quod aras omnes deorum necesse esse uideatur adorientem spectare" (Trad. do latim para o português por M. Justino Maciel).
} 
Os altares devem estar voltados para o oriente e colocados sempre numa cota inferior à das estátuas que estiverem no templo, a fim de que, levantando os olhos para a divindade, os que suplicam e oferecem sacrifício se possam dispor em diferentes níveis, cada um respeitando o que convém ao seu deus. As suas alturas serão planejadas, de forma que os altares a Júpiter e a todas as divindades celestes sejam elevados o mais alto possível; à Vesta, à Terra e ao Mar serão feitos baixos. Assim, com essas normas, serão atingidas com ponderação as formas idôneas dos $\operatorname{altares}^{24}$ (Vitr. De arch. 4.9.1).

Deste modo, para Vitrúvio, enquanto a entrada do templo deveria estar voltada para oeste, os altares em frente ao templo deveriam estar voltados para o leste; o que, segundo Gros (1976, p. 148), foi a forma pela qual Vitrúvio conciliou duas exigências litúrgicas, aquela que obriga o sacrificante a se voltar para o leste e aquela que fixa o olhar do oficiante na estátua de culto ao fundo do templo. Para este autor, tais exigências provavelmente possuem suas origens nos teóricos do helenismo asiático, visto que a orientação dos templos para oeste é uma característica singular de grandes santuários em Éfeso, Sardes e Magnésia do Meandro. Ainda como nos esclarece Pierre Gros, essa disposição ideal ditada por Vitrúvio traduz um conflito relativamente recente entre duas tendências, conflito este que o arquiteto tentou resolver conciliando a busca persistente de uma orientação itálica com a preocupação, que se firma desde a República Tardia, de seguir os costumes do mundo helênico.

Para os romanos, a arquitetura do templo baseada em precedentes helenísticos era um veículo importante para se apropriar culturalmente das conquistas imperiais de Roma. O poder de representar o que estava além das próprias fronteiras de Roma derivava do poder de uma sociedade imperial, e esse poder tomava a forma de uma reformulação ou reordenação das convenções locais da prática da construção romana. Construtores romanos representavam o que viam além de suas fronteiras, mas não sentiam necessidade de copiar edifícios helenísticos em sua

\footnotetext{
24 "Arae spectent ad orientem et semper inferiores sint conlocatae quam simulacra, quae fuerint in aede, uti suspicientes diuinitatem, qui supplicant, et sacrificent. Disparibus altitudinibus ad sui cuiusque dei decorem componantur. Altitudines autem earum sic sunt explicandae, uti Ioui omnibusque caelestibus quam excelsissimae constituantur, Vestae Terrae Matrique humiles conlocentur. Ita idoneae his institutionibus explicabuntur modulationibus ararum deformationes" (Trad. do latim para o português por M. Justino Maciel).
} 
totalidade. Eles sentiram-se à vontade para mudá-los da maneira que desejavam, de acordo com suas próprias tradições, materiais e necessidades funcionais (Stamper, 2005, pp. 66-67).

Tal aspecto é perceptível em Vitrúvio, que deixa entrever em várias passagens de sua obra que, apesar das regras rígidas para a construção dos diferentes edifícios públicos, era necessário também certa flexibilidade, de modo que o arquiteto deveria primar sempre pelo bom senso. Sendo um autor fortemente influenciado pela teoria grega, demonstrando grande admiração pelos monumentos erigidos em cidades gregas e helenísticas, de modo que a maioria dos referenciais de que ele se utiliza para pensar a construção de templos vem daí, ${ }^{25}$ Vitrúvio não deixou de propor adaptações para que o resultado final fosse harmonioso, por exemplo, quando trata da necessidade que por vezes se tornava imperiosa de se construir o templo sobre um pódio. No contexto romano, este servia para elevar o templo e torná-lo tão visível quanto os templos gregos que, naturalmente, possuíam lugar de destaque, visto que se localizavam em elevações do terreno.

Percebemos essa mescla entre características arquitetônicas gregas ou helenísticas, com características próprias da arquitetura que havia se desenvolvido em solo romano. Além disso, os templos, feitos ou revestidos em mármore, que passaram a ser construídos ou reconstruídos em Roma, competiam visualmente com os antigos templos de pedra calcária e madeira, que ainda se encontravam em pé, muitos dos quais haviam sido reformados por Augusto a partir de 28 a.C. Segundo Paul Zanker, sob o governo dele,

[...] os templos não deviam ser erigidos no estilo dos antigos - de pedra calcária com pesados tetos de madeira e decoração arcaica de terracota. Em vez disso, queria se imitar as mais belas e imponentes formas dos templos gregos, e inclusive superá-las, combinando-as ao mesmo tempo com as formas tradicionais dos templos itálico-romanos: um pódio alto, um pórtico profundo e um frontispício íngreme e carregado de uma rica decoração (Zanker, 2005, p. 133).

\footnotetext{
${ }^{25}$ De acordo com Taylor (2003, p. 25), "Vitrúvio não está interessado em caracterizar a arquitetura romana como nós a definimos. [...] seus mais importantes modelos eram gregos; sobre os mais "romanos" de todos os tipos de construção, tais como anfiteatros e arcos triunfais, ele se silencia, enquanto ele expõe longamente sobre alguns dos grandes templos do mundo grego. Sua adesão às tradições gregas é transferida para seu sistema intelectual, que toma emprestado termos e ideias da retórica e da teoria estética grega".
} 
Mare Nostrum, ano 2020, v. 11, n. 2.

Devemos tratar um pouco mais sobre a influência que as cidades gregas e helenísticas exerceram sobre Roma, pois, apesar de Augusto ter se utilizado amplamente de um referencial grego em suas construções, chegando mesmo a empregar em seu Fórum réplicas perfeitas das cariátides presentes no Erecteion de Atenas, a utilização de um estilo arquitetônico baseado nas cidades helenísticas não era algo novo no período do princeps.

No que se refere aos templos, durante a Realeza e em grande parte do período em que vigorou a República, foi utilizado em Roma o estilo de construção toscano e etruscoitálico. Após as Guerras Púnicas e a conquista de cidades gregas e helenísticas, diferentes templos em estilo jônico foram erguidos em Roma. De acordo com Stamper (2015, p. 216), esses templos representam bem a extensão em que a influência helenística representada pela ordem jônica foi predominante em Roma durante grande parte do segundo e começo do primeiro século a.C. Este estilo tornara-se atraente e aceitável para os construtores romanos e para o público depois da captura da Grécia e da Ásia Menor, embora fosse usado tipicamente em conjunto com os planos tradicionais etruscos, ou adaptado para atender às necessidades de cultos ou condições locais. Para este autor, como os templos jônicos da Grécia continental e da Costa Jônica tornaram-se acessíveis como modelos e fontes de material de construção, seu estilo de arquitetura tornou-se comum na prática romana. Esta tendência continuou até o final do segundo século a.C, quando o puro estilo coríntio passou a dominar a arquitetura do templo romano, tanto em sua forma canônica helênica como em variações regionais, quando arquitetos e construtores em Roma e suas colônias começaram a desenvolver suas próprias interpretações. Com isso, o estilo coríntio é o estilo por excelência usado por Augusto e seus contemporâneos.

A ordem coríntia possui capitéis graciosamente trabalhados imitando folhas de acanto. Tais capitéis, segundo Vitrúvio ${ }^{26}$, tiveram origem na cidade de Corinto, pelas mãos de Calímaco, escultor cuja arte de trabalhar o mármore possuía elegância e sutileza. Apesar de capitéis coríntios já existirem em Roma, Augusto se utilizou de tal forma desta tipologia de colunata que ela passou a ser uma característica dos empreendimentos arquitetônicos desenvolvidos por ele. Segundo Zanker:

\footnotetext{
${ }^{26}$ Sobre a origem da ordem coríntia, Indra McEwen (2003, p. 215) esclarece que os mais antigos protótipos de capitéis coríntios foram desenvolvidos em Atenas, não em Corinto, na segunda metade do quinto século a.C., período em que viveu o escultor ateniense Calímaco.
} 
O dórico, bem como o jônico, foram quase completamente substituídos pela ordem coríntia. [...] Os novos templos augustanos foram expressamente concebidos como uma "composição mista". O pódio, o pronau e o frontispício procedem da própria tradição cultural. Já no que se refere à altura das colunas, à forma dos capitéis e à organização das fachadas se seguiam modelos helenísticos (Zanker, 2005, pp. 299-300).

Ao tratar da ordem coríntia, Vitrúvio a relaciona a um contexto diferente daquele que usou para tratar das outras ordens, pois, se a ordem dórica havia surgido com Doro, filho de Heleno (Vitr. De arch. 4.1.3), e a ordem jônica nas colônias fundadas por Íon (Vitr. De arch. 4.1.4), a ordem coríntia havia surgido da observação de Calímaco que, ao ver que um acanto tinha crescido sobre o túmulo de uma jovem e envolvido um cesto deixado lá por sua ama, resolveu construir colunas inspiradas nestas formas (Vitr. De arch. 4.1.10). Na obra de Vitrúvio, a ordem coríntia se liga, assim, à renovação, ao renascimento, pois foi inspirada na vida (acanto) que surgiu sobre um túmulo. De acordo com McEwen:

Uma vez nomeada e localizada, a ordem coríntia não era mais apenas sobre Corinto, é claro, mas sobre Roma e sua missão civilizadora. A forma arquitetônica específica em que Vitrúvio encapsula o renascimento da cidade poderia, então, passar a anunciar o renascimento de todo o mundo. Gerada por forças naturais, a ordem coríntia era a ordem da futura renovação, não, como as veneráveis ordens dórica e jônica, ordens do passado (McEwen, 2003, p. 220).

No período de Augusto, a ordem coríntia passou a ser o recurso estilístico mais amplamente usado. Com a sua utilização, percebemos a relação que se estabeleceu entre restauração e renovação, de modo que a restauração religiosa e arquitetônica simbolizou também a restauração da res publica, a coisa pública, que Otávio teria conservado frente ao perigo que esta corria de cair sob o domínio estrangeiro. Ameaça esta representada pela ligação entre Marco Antônio e Cleópatra, tal como foi amplamente propagado no período $^{27}$.

\footnotetext{
${ }^{27}$ A vitória em Ácio teria conservado a res publica, ou pelo menos, este era o desejo do Senado ao grafar em mármore tal inscrição, provavelmente pertencente ao arco triunfal que teria sido construído para Otávio no fórum romano em 29 a.C. Na inscrição (CIL 6.873 = ILS 81) presente no bloco de mármore de 2 metros de comprimento podia-se ler SENATVS POPVLVSQVE ROMANVS / IMP. CAESARI DIVI IVLI F. COS.
} 
Mare Nostrum, ano 2020, v. 11, n. 2.

De acordo com Zvi Yavetz (2002, p. 18), “deve ter ocorrido a Augusto que a melhor estratégia para a introdução de uma nova tradição seria o reavivamento de uma antiga tradição", por este motivo ele teria se esforçado com tanto empenho nesta direção. Desta forma, a restauração dos templos, bem como o reavivamento dos preceitos morais estabelecidos pelos antigos, foram medidas adotadas por Augusto para demonstrar seu interesse com a res publica. Com isso, inaugurou-se um período novo na história de Roma e tal renovação foi expressa de modo singular pela ordem coríntia.

Em termos de técnica, neste período, o uso massivo do estilo coríntio fez com que os entalhadores de pedra ganhassem experiência e a qualidade do trabalho melhorou acentuadamente. Não havia duas estruturas de templos exatamente iguais, embora muitas delas compartilhassem características comuns. $\mathrm{O}$ vocabulário arquitetônico tinha claras origens gregas, mas havia uma variedade de interpretações romanas, cada templo incorporando uma forma diferente de capitel coríntio, tratamento de molduras nos entablamentos $^{28}$, detalhes de modilhões ${ }^{29}$, sem mencionar as variações nos tipos de plano (Stamper, 2015, p. 222).

\section{Diferenças entre as regras de Vitrúvio e as construções de Augusto}

Nem todas as concepções desenvolvidas por Vitrúvio no que se refere às ordens arquitetônicas e suas aplicações na construção de templos foram seguidas pelos construtores de Augusto. Por exemplo, Vitrúvio defendia que o decoro era conseguido nos templos ao se cumprir certos princípios, de tal forma que as diferentes características dos deuses melhor se adequavam a diferentes estilos arquitetônicos. Ele recomendava que divindades como Júpiter Tonante, Céu, Sol e Lua deveriam possuir templos sem telhados. Divindades como Minerva, Marte e Hércules, devido à sua força, deveriam possuir templos no estilo dórico, desprovidos de ornatos. Os templos dedicados a Vênus, Flora, Proserpina e às Ninfas das Fontes deveriam ser erigidos no estilo coríntio, devido à delicadeza de tais divindades. E às deusas Juno, Diana, ao deus Líbero e outros deveriam ser erguidos templos jônicos, pois se encontravam em uma posição intermediária e não

QVINCT. / COS. DESIGN. SEXT. IMP. SEPT. / RE PVBLICA CONSERVATA (O Senado e o povo romano, para o Imperador César, filho do divino Júlio, cônsul pela quinta vez e designado para um sexto consulado, por conservar a República).

${ }^{28}$ Entablamento é a parte acima dos capitéis, composto de arquitrave, friso e cornija.

${ }^{29}$ Ornamentos em forma de $\mathrm{S}$ invertido, dispostos horizontalmente abaixo da cornija. 
poderiam ter nem templos com as características severas do estilo dórico nem com a delicadeza do estilo coríntio (Vitr. De arch. 1.2.5).

Nesta passagem, podemos notar um posicionamento diferenciado entre Vitrúvio e Augusto, pois tais recomendações de Vitrúvio expressam claramente o seu espírito conservador, o que não foi correspondido em sua totalidade por Augusto, que mesclou inovação e tradição em seu governo. No que se refere à construção de novos templos, Augusto tinha predileção pelas colunatas coríntias, independentemente do deus ao qual o templo era dedicado, como, por exemplo, o templo de Marte Vingador, parte central de seu novo fórum consagrado em 2 a.C.

Outro ponto referente à construção de templos no qual Vitrúvio se distingue de Augusto diz respeito ao local onde os templos deveriam ser erguidos. Enquanto que, para Vitrúvio (De arch. 1.7.1), os templos dedicados a Apolo e ao deus Líbero deveriam ser erguidos próximos ao teatro, vemos com Augusto que seu novo templo dedicado a Apolo se localizava próximo a sua própria casa, no Palatino. No mesmo trecho, encontramos outra distinção entre as recomendações de Vitrúvio e a prática construtiva de Augusto, pois, enquanto Vitrúvio defende que, segundo os arúspices etruscos, os templos dedicados a Marte deveriam ser edificados fora da muralha, para evitar dissensão armada entre os cidadãos, e defender a cidade dos inimigos, salvando-a do perigo da guerra, o princeps constrói seu suntuoso templo dedicado a Marte dentro das muralhas, erigido em local de destaque no centro de seu Fórum.

\section{O templo de Júpiter Tonante}

Para exemplificar a importância da análise conjunta de documentos textuais e materiais no que se refere aos templos construídos por Augusto, nos utilizamos do templo de Júpiter Tonante. O votum e a dedicatio deste templo perpassam os anos 20 a.C. Sabemos por meio de Suetônio (Aug. 29) que, no ano de 26 a.C., em meio às campanhas, enquanto marchava à noite com suas tropas sob uma tormenta, um raio atingiu sua liteira e matou um escravo que caminhava à frente; grato por não ter sido ele a vítima de tal acontecimento, Augusto prometeu a construção de um templo, em Roma, a Júpiter Tonante. Como vimos, tal templo foi consagrado em 22 a.C.

O templo se localizava próximo à entrada para o Monte Capitolino. Tinha paredes de mármore maciço (Plínio. Naturalis Historia. 36.50) e sua estátua de culto era um original feito pelo escultor grego Leocares, século IV a.C., (Plin. HN. 34.79). De acordo 
Mare Nostrum, ano 2020, v. 11, n. 2.

com Suetônio (Aug. 89), o templo se tornou muito popular, tanto que Augusto teria sonhado com Júpiter Capitolino protestando que a nova construção estava retirando adoradores de seu templo, ao que Augusto respondeu que Júpiter Tonante era apenas o porteiro de Júpiter Capitolino e, devido a isso, ele pendurou sinos nos beirais do novo templo.

Não se sua sabe a localização exata e, sobre sua aparência, sabemos apenas o que aparece em diversas moedas do período, cunhadas na Hispânia. Por exemplo, no aureus (RIC I 66. Figura 2) cunhado por volta de 19 a.C., no qual vemos no anverso a efígie de Augusto com a inscrição CAESAR AVGVSTVS. No reverso, temos a representação provável de como teria sido o templo de Júpiter Tonante, um templo hexástilo com colunata coríntia, no centro encontrando-se a estátua de culto nua, a mão esquerda elevada, segurando um longo cetro, e a direita para baixo segurando um raio. Este templo "não era imponente no tamanho, mas se distinguia pelo esplendor de seus materiais, a riqueza de sua decoração, e a importância de sua localização" (Galinsky, 1998, p. 296).
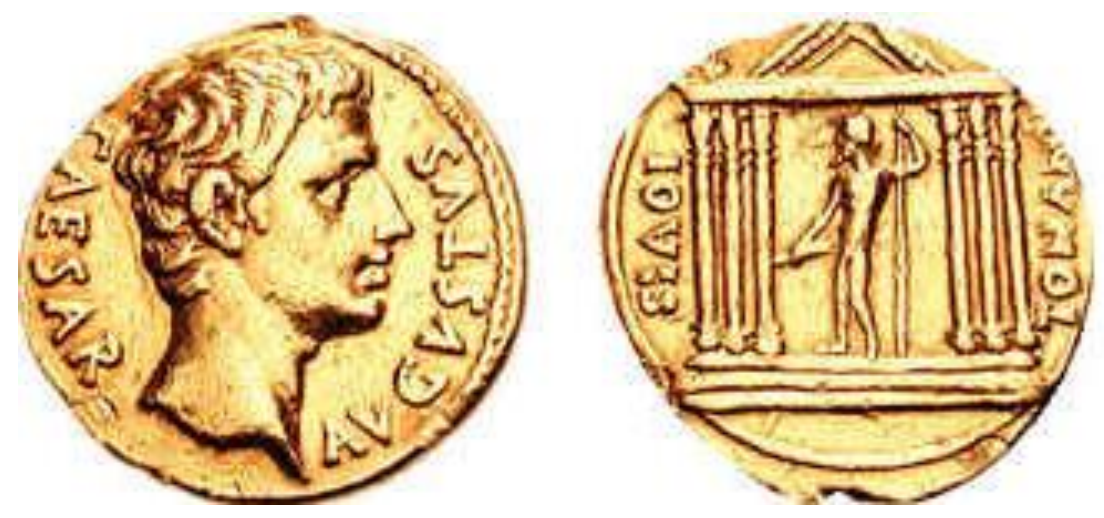

Figura 2. Moeda de Ouro. Áureo.

Fonte: RIC I $66^{30}$

Na ausência de vestígios arqueológicos pertencentes ao templo, tais moedas, aliadas às fontes textuais, nos auxiliam no estudo e na compreensão acerca desta importante construção do período augustano. Ademais, devemos lembrar que cada vez mais as moedas se tornaram um instrumento de propaganda, transmitindo uma determinada imagem ou mensagem referente àquele a quem a moeda se referia. Além disso, "as pessoas no mundo romano não contavam com os estímulos visuais com os quais contamos atualmente, por isso elas eram muito mais observadas e manipuladas no passado do que

${ }^{30}$ RIC I 66 ou BMCRE 364 - The British Museum, Londres, Inglaterra. 
no presente" (Gonçalves, 2013, p. 44). Estas moedas demonstram a importância que tais monumentos possuíam na sociedade antiga, servindo como um memorial do grande acontecimento do qual se tratava a construção de um templo, mantendo vivos na memória das pessoas os feitos de Otávio e as obras construídas por ele.

\section{Considerações Finais}

A partir destes apontamentos, podemos perceber a grande importância que a construção e a restauração de templos tiveram ao longo da história de Roma e como a mesma foi utilizada por Augusto em seu governo. Analisamos alguns dos aspectos formais relacionados às construções de templos e suas principais regras construtivas, a partir dos vestígios materiais encontrados nos sítios arqueológicos, bem como por meio das fontes textuais, como a obra de Vitrúvio.

$\mathrm{Na}$ Antiguidade, portanto, o templo desempenhava um importante papel nas atividades religiosas desenvolvidas pelos indivíduos, sendo considerado a moradia das divindades, que se encontravam ali presentes através de suas estátuas cultuais. Este é, talvez, um dos pontos que mais distingue a noção de templo que possuímos na atualidade daquela compartilhada pelos antigos, pois, devido ao fato de serem a moradia das divindades, os templos estavam envoltos em uma atmosfera de respeito e sacralidade, possuindo, assim, regras que limitavam a circulação de pessoas dentro deles, de modo tal que os mesmos não se encontravam abertos aos indivíduos sempre que se quisesse adentrá-lo.

Recebido: $29 / 07 / 2020$

Aprovado: $29 / 10 / 2020$ 
Mare Nostrum, ano 2020, v. 11, n. 2.

\section{REFERÊNCIAS BIBLIOGRÁFICAS}

\section{Fontes}

Horace. (2004). Odes and Epodes (Trad. Niall Rudd). The Loeb Classical Library. Harvard: University Press.

Pliny. (1855). Natural History (Trad. John Bostock \& H.T. Riley). London: Taylor and Francis, Red Lion Court, Fleet Street.

Res Gestae Divi Augusti. (2007). (Trad. M. Trevizam; P. S. Vasconcellos \& A. M. Rezende). Belo Horizonte: Editora UFMG.

Suetônio. (2007). Vida de Augusto. (Trad. M. Trevizam; P. S. Vasconcellos \& A. M. Rezende). Belo Horizonte: Editora UFMG.

Titus Livius. (1905). History of Rome. (Trad. Canon Roberts). London: Everyman's Library Classical.

Vitrúvio. (2007). Tratado de Arquitetura. Trad. M. Justino Maciel. São Paulo: Martins.

\section{Obras}

Barton, I. M. (1995). Religious Buildings. In Ian M. Barton (Ed.), Roman Public Buildings (pp. 67-85). Liverpool: Liverpool University Press.

Beard, M.; North, J. \& Price, S. (2004). Religions of Rome. Vol. 1. Cambridge: Cambridge University Press.

Beltrão, C. (2008). Arte, Religião e Poder na Roma Antiga: Inovações e Conservadorismo na República Tardia. In Maria Regina Candido (Org.), Roma e as Sociedades da Antiguidade: Política, Cultura e Economia (pp. 15-20). Rio de Janeiro: NEA/UERJ.

Benoist, L. (1999). Signos, Símbolos e mitos. Lisboa: Edições 70.

Egelhaaf-Gaiser, U. (2007). Roman Cult Sites: A Pragmatic Approach. In J. Rüpke, A companion to Roman Religion (pp. 205-221). Malden: Blackwell Publishing Ltd.

Favro, D. (2008). The Urban Image of Augustan Rome. Los Angeles: Cambridge University Press.

Funari, P. P. (2005). Fontes arqueológicas: os historiadores e a cultura material. In Carla Pinsky \& Carla Bassanezi (Orgs.). Fontes Históricas (pp. 81-110). São Paulo: Contexto. 
Galinsky, K. (1998). Augustan Culture: An interpretive introduction. New Jersey: Princeton University Press.

Gargola, D. J. (1995). Lands, Laws \& Gods: Magistrates \& Ceremony in the Regulation of Public Lands in Republican Rome. Chapel Hill \& London: UNC Press.

Gonçalves, A. T. M. (2013). A Noção de Propaganda e sua Aplicação nos Estudos Clássicos: O Caso dos Imperadores Romanos Septímio Severo e Caracala. Jundiaí: Paco Editorial.

Gros, P. (1976). Aurea Templa: recherches sur l'architecture religieuse de Rome à l'époque d'Auguste. BEFAR 231.

Gros, P. (2002). L'architecture romaine du début du Illème siècle av. J.-C. à la fin $d u$ Haut-Empire 1: Les monuments publics. Paris: Picard.

Haselberger, L. (2007). Urbem Adornare: Rome's urban metamorphosis under Augustus. Pennsylvania: JRA Supp. 64.

Kähler, H. (1965). The Art of Rome and Her Empire. New York: Greystone Press.

McEwen, I. K. (2003). Vitruvius: writing the body of architecture. Massachusetts: Mit Press.

Orlin, E. (2002). Temples, Religion, and Politics in the Roman Republic. Boston: Brill Academic Publishers.

Oxford Latin Dictionary. (2012). Oxford: University Press.

Richardson, L. (1992). A New Topographical Dictionary of Ancient Rome. London: Johns Hopkins University Press.

Scheid, J. (2007). Augustus and roman religion. In Karld Galinsky (Ed.), The Age of Augustus (pp. 175-193). New York: Cambridge University Press.

Scheid, J. (2009). Les restaurations religieuses d'Octavien. In Le Principat d'Auguste: Realites et representations du pouvoir Autour de la Res publica restituta (pp. 119128). Rennes: Presses Universitaires de Rennes.

Stamper, J. W. (2005). The Architecture of Roman Temples: The Republic to the Middle Empire. Cambridge: Cambridge University Press.

Stamper, J. W. (2015). Urban Sanctuaries: The Early Republic to Augustus. In Roger B. Ulrich \& Caroline K. Quenemoen (Eds.), A Companion to Roman Architecture (pp. 207-227). Malden: Blackwell Publishing Ltd.

Stewart, P. (2003). Statues in Roman Society: Representation and Response. New York: Oxford University Press.

Strong, D. E. (1968). The Administration of Public Building in Rome During the Late Republic and Early Empire. Bulletin of the Institute of Classical Studies, n. 15, 97109. 
Mare Nostrum, ano 2020, v. 11, n. 2.

Taylor, R. (2003). Roman Builders: A study in architectural process. Cambridge: Cambridge University.

Yavetz, Z. (2002). The Res Gestae and Augustus' Public Image. In Fergus Millar \& Erich Segal (Eds.), Caesar Augustus: Seven aspects (pp. 1-36). New York: Oxford University Press.

Zanker, P. (2005). Augusto y el poder de las imagines. Madrid: Alianza Forma.

Ziolkowski, A. (1992). The temples of mid-republican Rome and their historical and topographical context. Roma: «L'Erma» di Bretschneider. 


\section{CONSTRUCTION OF TEMPLES:}

\section{The Religious Architecture in Augustan Age}

\section{ABSTRACT}

The temple was one of the main expressions of material culture with regard to religion and religiosity in the Ancient World. In the Rome of the Augustan Age, the same thing happened, so much so that the construction of temples obeyed precise rules, in addition to being linked to political strategies, since it conferred glory on those who were responsible for it. In this paper we analyze the process of building temples, their general characteristics and the main rules for the construction of the houses of the deities, as well as the importance with which the construction of temples had in this period. For that, we used the De Architectura, of Vitruvius, as well as the vestiges of the material culture of that time.

\section{KEYWORDS}

Temples; Augustus; Vitruvius. 